\title{
Immunocytochemical demonstration of human immunodeficiency virus infected cells in the cerebrospinal fluid
}

\author{
ERWIN STARK, JUDITH HAAS, JEAN-PIERRE MALIN, ULRIKE BRUNKHORST* \\ From the Neurological Clinic and Department of Immunology* of the Hannover Medical School, Hannover, \\ Federal Republic of Germany
}

SUMMARY Although involvement of the central nervous system represents one of the most common manifestations of the acquired immunodeficiency syndrome (AIDS), a standard diagnostic test for this condition has not yet been established. At necropsy human immunodeficiency virus (HIV) has been demonstrated in brain macrophages in such patients. HIV antigen was detected in CSF macrophages by immunocytochemistry in six out of $11 \mathrm{HIV}$ infected patients. In addition to the detection of intrathecal synthesis of anti-HIV antibodies this method may be suitable for early diagnosis of CNS involvement in AIDS patients.

Epidemiological estimations foresee that subacute encephalitis due to human immunodeficiency virus (HIV) will become the most common inflammatory disease of the central nervous system. In addition this virus can cause vacuolar myelopathy, peripheral neuropathy or chronic meningitis. HIV has been cultured from cerebrospinal fluid of patients affected by these diseases ${ }^{1}$ and viral antigen has been demonstrated in brain macrophages of such patients post mortem. ${ }^{2}$

\section{Materials and methods}

CSF from 11 HIV-seropositive adult patients was collected. HIV infection was ascertained by Western blot. In all cases the stage of the disease was assessed according to the Walter Reed $^{3}$ and the new Center for Disease Control ${ }^{4}$ classification. By clinical impression, none of the patients was severely demented. Some of them showed neuropsychological involvement detected by standard testing procedures (HAWIE test, Kimura recurring figure test). Except from one female with CNS toxoplasmosis, neurological impairment in all other patients was only mild. Cytospin slides from CSF were prepared as previously

Address for reprint requests: Dr E Stark, Neurological Clinic, Medizinische Hochschule Hannover, Postfach 6101 80, D 3000 Hannover 61, Federal Republic of Germany.

Received 24 November 1987 and in revised form 11 March 1988. Accepted 15 March 1988 described. ${ }^{5}$ In brief, the CSF was centrifugated $\left(800 \mathrm{~g}, 4^{\circ} \mathrm{C}\right.$, $15 \mathrm{~min})$. The supernatant was then removed for other investigations and the remainder resuspended in medium 199 /fetal bovine'serum. From this cell suspension slides were prepared using a cytocentrifuge $(80 \mathrm{~g}, 10 \mathrm{~min})$. The slides were fixed in acetone and stored at $-70^{\circ} \mathrm{C}$ until further processing. After thawing a double bridge alkaline phosphatase anti alkaline phosphatase (APAAP) immunoenzyme staining was performed. ${ }^{6}$ A murine monoclonal antibody against a HIV core structural protein (p 24, Du Pont) was used at a dilution of $1: 100$ in PBS (phosphate buffered saline) as the primary antibody. Rabbit anti-mouse IgG was employed as second antibody and finally mouse monoclonal APAAP was used as third antibody. Second and third antibody were applied twice in order to enhance the staining intensity. The slides were rinsed in PBS between all incubation procedures. Alkaline phosphatase was made visible using fast red TR, naphthol AS MX phosphate and levamisol in TBS (pH 8.6, 0.1 M). Finally slides were fixed in $0.6 \%$ buffered glutardialdehyde, counterstained with haemalum and mounted in Aquamount (Gurr). As negative controls, CSF samples from patients with other neurological diseases were stained in the same manner, in addition cytospin slides from $\mathrm{HIV}^{+}$patients were immunostained using an irrelevant monoclonal antibody of no defined specificity (Sigma).

\section{Results}

The results of our study are summarised in the table. In six out of 11 CSF samples HIV p 24 containing cells 
Table Clinical and CSF data of all subjects

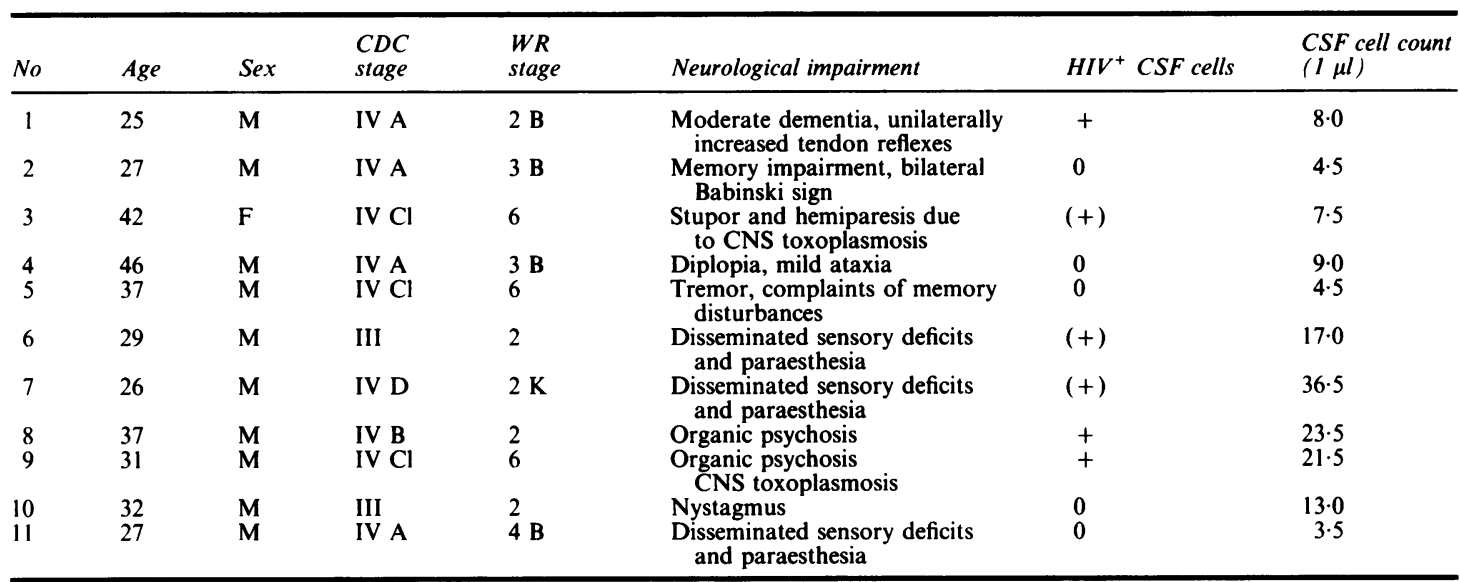

Immunostaining results: $+=$ intensive staining of at least $1 \%$ of the CSF cells, $(+)=$ weaker staining or less positive cells.

could be detected. Most of the cells could be identified as monocytes and macrophages; some of them had an atypical nucleus with coarse chromatin. Some different staining patterns could be observed: some cells showed diffuse scattered granules within the entire cytoplasm (fig), others mixed homogeneous and granular staining of the submembranous part of the cytoplasm. Rarely, compact circumscript staining resembling inclusion bodies were found. In CSF samples with mild pleocytosis a few thousand cells were obtained on each slide. In some cases only a small number of positive cells could be observed, in others up to $5 \%$ of the cells were immunostained. Positive lymphocytes were scarce; no such cells were observed in samples from nine patients, a single positive lymphocyte respectively was found only in two samples. Routine cytological preparations did not reveal multinucleated cells in any of our cases. Neither in the

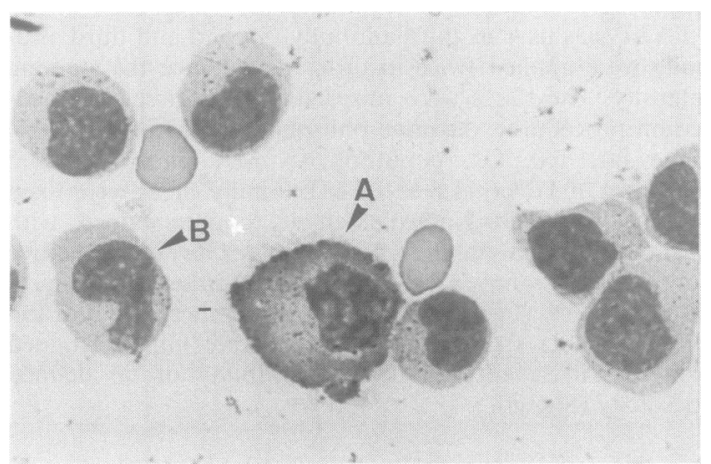

Fig Anti HIV p24 immunostaining. One cell (probably monocyte/macrophage) shows dense staining, which is accentuated in the submembranous part of the cytoplasm (A). All other cells, including a monocyte (B) are negative. cells from non-AIDS patients stained for HIV nor in the control stains using the irrelevant antibody was nonspecific staining observed.

\section{Discussion}

Secondary CNS involvement due to infections or neoplasms is a frequent complication in patients suffering from the acquired immunodeficiency syndrome. ${ }^{7}$ Recently, several distinct neurological syndromes have been described: a subacute encephalitis which? leads to progressive dementia and brain atrophy ${ }^{8}$ and a vacuolar degeneration of the spinal cord with ataxia, paraparesis and incontinence. ${ }^{9}$ Furthermore, chronic meningitis and peripheral neuropathy may be caused by HIV. ${ }^{710}$ Although some studies have shown that HIV may be cultured in glial cells, ${ }^{11}$ post mortem examinations have shown virus proteins ${ }^{12}$ and nucleic acids $^{1}$ in monocytes and macrophages of affected brains. According to the innocent bystander theory, neuroglial cells are only damaged by viral proteins or by metabolic products of the infected cells. Routine laboratory tests for the diagnosis of central nervous system involvement by HIV have not yet been established. A possible approach to this end could be by raising the virus in $T$ lymphocyte cultures. ${ }^{13}$ This method is very time-consuming and negative cultures can be discarded not sooner than 4 weeks. This technique seems to be of highest sensitivity; however, false positive results due to infected $T$ cells are theoretically possible. The demonstration of intrathecal production of anti-viral antibodies has also been adapted to AIDS. ${ }^{14}$ This method is performed more rapidly, but if more than one infection of the CNS occurs simultaneously, this test may result in a false negative. In these cases only the dominant antibody may be 
detected. Still another possibility is the direct demonstration of HIV antigen in the CSF by an enzyme linked sorbent assay (ELISA). ${ }^{15}$ Whether one of these methods or the demonstration of immunodeficiency viral proteins in CSF cells as described here is superior in specificity and sensitivity should be the aim of further studies. The question as to which method allows the earliest diagnosis of CNS involvement is of great interest, because patients with neurological manifestations of AIDS may have a poorer prognosis. In these patients early therapy with HIV inhibitory substances would be required to prevent further neurological damage. Further prospective studies will be necessary to investigate how many, if not all, of the patients in whom CNS infection can be demonstrated will develop a severe progressive dementia.

\section{References}

1 Ho DD, Rota TR, Schooley RT, et al. Isolation of HTLV-III from CSF and neural tissues of patients with AIDS-related neurological syndromes. Ann Inst Pasteur/Virol 1987;138:137-44.

2 Puarola-Sune T, Navia BA, Cordon-Cardo C, et al. HIV antigen in the brains of patients with the AIDS dementia complex. Ann Neurol 1987;21:490-6.

3 Redfield RR, Wright DC, Tramont EC. The Walter Reed staging classification for HTLV III/LAV infection. $N$ Engl J Med 1986;314:131-2.

4 Center for Disease Control. Classification system for human T-lymphotropic virus type III/lymphadenopathy-associated virus infections. Ann Intern Med 1986;105:234-7.

5 Stark E, Wurster U. Preparation procedure for cerebrospinal fluid that yields cytologic samples suitable for all types of staining, including immunologic and enzymatic. Acta Cytol 1987;31:374-6.
6 Erber WN, Pinching AJ, Mason DY. Immunocytochemical detection of $\mathrm{T}$ and $\mathrm{B}$ cell populations in routine blood smears. Lancet 1984;i:1042-5.

7 Snider WD, Simpson DM, Nielsen S, et al. Neurological complications of acquired immune deficiency syndrome: analysis of 50 patients. Ann Neurol 1983;14: 403-18.

8 Nielsen S, Petito CK, Irmacher CD, et al. Subacute encephalitis in acquired immune deficiency syndrome: postmortem study. Am J Clin Pathol 1984;82:678-82.

9 Petito CK, Navia BA, Cho ES, et al. Vacuolar myelopathy pathologically resembling subacute combined degeneration in patients with the acquired immunodeficiency syndrome. $N$ Engl J Med 1985; 312:874-9.

10 Levy RM, Bedesen DE, Rosenblum ML. Neurological manifestations of the acquired immunodeficiency syndrome (AIDS): experience at UCSF and review of the literature. J Neurosurg 1985;62:475-95.

11 Cheng-Mayer C, Ruttka JT, Rosenblum M, et al. Human immunodeficiency virus can productively infect cultured human glial cells. Proc Natl Acad Sci USA 1987;84:3526-30.

12 Vazeuz R, Brousse N, Jarry A, et al. AIDS subacute encephalitis. Identification of HIV-infected cells. Am J Pathol 1987;126:403-10.

13 Ho DD, Rota TR, Schooley RT, et al. Isolation of HTLV-III from cerebrospinal fluid and neural tissue of patients with neurologic syndromes related to the acquired immunodeficiency syndrome. $N$ Engl $J$ Med 1985;313:1493-7.

14 Resnick L, DiMarzo-Veronese F, Schüpbach J, et al. Intra-blood-brain-barrier synthesis of HTLV-IIspecific IgG in patients with neurologic symptoms associated with AIDS or AIDS-related complex. N Engl J Med 1985;313:1498-504.

15 Goudsmit J, DeWolf F, Paul DA, et al. Expression of human immunodeficiency virus antigen (HIV-Ag) in serum and cerebrospinal fluid during acute and chronic infection. Lancet 1986;ii:177-80. 